\title{
A Brief Review of Bioactive Metabolites Derived from Deep-Sea Fungi
}

\author{
Yan-Ting Wang, Ya-Rong Xue and Chang-Hong Liu * \\ State Key Laboratory of Pharmaceutical Biotechnology, School of Life Science, \\ Nanjing University; 163 Xianlin Avenue, Nanjing 210023, Jiangsu, China; \\ E-Mails: wangyanting2012@qq.com (Y.-T.W.); xueyr@nju.edu.cn (Y.-R.X.) \\ * Author to whom correspondence should be addressed; E-Mail: chliu@nju.edu.cn; \\ Tel./Fax: +86-25-8968-5469.
}

Academic Editor: Johannes F. Imhoff

Received: 2 June 2015 / Accepted: 14 July 2015 / Published: 23 July 2015

\begin{abstract}
Deep-sea fungi, the fungi that inhabit the sea and the sediment at depths of over $1000 \mathrm{~m}$ below the surface, have become an important source of industrial, agricultural, and nutraceutical compounds based on their diversities in both structure and function. Since the first study of deep-sea fungi in the Atlantic Ocean at a depth of $4450 \mathrm{~m}$ was conducted approximately 50 years ago, hundreds of isolates of deep-sea fungi have been reported based on culture-dependent methods. To date more than 180 bioactive secondary metabolites derived from deep-sea fungi have been documented in the literature. These include compounds with anticancer, antimicrobial, antifungal, antiprotozoal, and antiviral activities. In this review, we summarize the structures and bioactivities of these metabolites to provide help for novel drug development.
\end{abstract}

Keywords: deep-sea fungi; bioactive compounds; anticancer; antimicrobial; antiviral; antifungal

\section{Introduction}

Fungi are well known for their vast diversity of secondary metabolites, which include many life-saving drugs and highly toxic mycotoxins [1]. Deep-sea fungi are the fungi that inhabit the sea and its sediment at a depth of over $1000 \mathrm{~m}$ below the surface [2]. Although the conditions in deep-sea environments are extreme and can be characterized by the absence of sunlight irradiation, predominantly 
low temperature, high hydrostatic pressure, and oligotrophy, it has been reported that fungi are abundant and diverse in these environments [3-5]. According to literature surveys, the first documented deep-sea fungi were isolated from the Atlantic Ocean at a depth of $4450 \mathrm{~m}$ approximately 50 years ago [6]; however, it was not until 2006 that the first bioactive metabolite of the deep-sea fungus Chromocleista sp. was described by Park et al. [7]. After that, many biologically active secondary metabolites have been isolated from deep-sea fungi and evaluated for their activities against cancer, pathogenic fungi, bacteria, virus, and larval settlement [1,7-9]. Many bioactive metabolites have shown potential as an excellent resource for the discovery of new drugs $[10,11]$. The intent of this review is to summarize the new and/or bioactive compounds produced by deep-sea fungi.

\section{Diversity of Deep-Sea Fungi}

Although the environmental conditions in the deep sea cannot support many organisms, it is now well recognized that the deep sea is home to rich and diverse microbial communities [12]. Apart from bacteria and archaea [13-15], fungi in deep-sea environments have been extensively studied [5,16,17] in the past 50 years since the isolation of the first reported deep-sea fungi from the Atlantic Ocean at a depth of $4450 \mathrm{~m}$ [6]. The investigated deep-sea environments include the Gulf of Mexico [12], the Mariana Trench (11,500 m) [18], the Chagos Trench (5500 m) [19], the Central Indian Basin (5000 m) [17], the South China Sea [20-23], the Antarctic Ocean [24,25], the Eastern Mediterranean [26], the Pacific Ocean [27], the Black Sea [28], the North Pacific Ocean [29], the East Indian Ocean [30], and the Central Arabian Sea [31]. For instance, Xu et al. [32] have described 175 deep-sea fungi that were isolated from 15 sediments in the Eastern Pacific Ocean, the South Atlantic Ocean, and the Southwest Indian Ocean. These fungi, including 93 yeast and 82 filamentous fungi, belonged to 17 genera: Rhodosporidium, Rhodotorula, Aspergillus, Cladosporium, Penicillium, Alternaria, Fusarium, Acremonium, Phoma, Tritirachium, Chaetomium, Exophiala, Engyodontium, Sistotrema, Schizophyllum, Tilletiopsis, and Hormonema. Most of the fungi were either isolated using culture-dependent method or proved based on sequence analysis of the ribosomal RNA gene, and are classified into Ascomycota and Basidiomycota. Particularly, Aspergillus and Penicillium belonging to Ascomycota are dominant in deep-sea environments [32,33].

Along with the development of modern instruments and techniques used for sampling and researching, more and more deep-sea fungi have been collected [20,22,34-38]. The rich and diverse communities of deep-sea fungi increase the pool of fungi available for natural bioactive product screening and new drug discoveries.

\section{Bioactive Metabolites of Deep-Sea Fungi}

\subsection{Anticancer}

With the changes in the living environment, cancer has become one of the major causes of death worldwide [39]. Many techniques have been applied to control cancer, such as surgery, radiotherapy, and chemotherapy. Out of all these techniques, chemotherapy is the most commonly used and the most effective method to treat cancer so far. However, the application of chemotherapeutic agents has been greatly restricted because most of them have high cell toxicity and provoke severe adverse reactions in 
human beings [40]. Therefore, seeking for high-efficiency, low-toxicity anticancer agents from deep-sea fungi has become one of the research subjects in the current pharmacy field.

\subsubsection{Polyketides Compounds}

Eight new chromones, engyodontiumones A-H (1-8), and eight known polyketides (9-16) (Figure 1) have been isolated from the deep-sea fungus Engyodontium album DFFSCS021. These polyketide compounds show a significant selective cytotoxicity against human histiocytic lymphoma U937 cell line with $\mathrm{IC}_{50}$ of 4.9-8.8 $\mu \mathrm{M}$. In addition, compounds $\mathbf{8}, \mathbf{1 2}$, and $\mathbf{1 3}$ exhibit mild antibacterial activity against Escherichia coli and Bacillus subtilis, and compound $\mathbf{1 2}$ shows potent antilarval activity against barnacle Balanus amphitrite larval settlement [41].<smiles>[R]OC(=O)c1c([R])ccc2oc3cc([R])cc(O)c3c(=O)c12</smiles>

$1 \mathrm{R}_{1}=\mathrm{CH}_{3}, \mathrm{R}_{2}=\mathrm{OCH}_{3}, \mathrm{R}_{3}=\mathrm{CH}_{2} \mathrm{OH}$ $2 \mathrm{R}_{1}=\mathrm{CH}_{3}, \mathrm{R}_{2}=\mathrm{Cl}, \mathrm{R}_{3}=\mathrm{CH}_{2} \mathrm{OH}$ $9 \mathrm{R}_{\mathbf{1}}=\mathrm{CH}_{3}, \mathrm{R}_{\mathbf{2}}=\mathrm{H}, \mathrm{R}_{3}=\mathrm{CH}_{2} \mathrm{OH}$ $10 \mathrm{R}_{1}=\mathrm{CH}_{3}, \mathrm{R}_{2}=\mathrm{OH}, \mathrm{R}_{3}=\mathrm{CH}_{3}$ $11 \mathrm{R}_{1}=\mathrm{CH}_{3}, \mathrm{R}_{2}=\mathrm{OH}, \mathrm{R}_{3}=\mathrm{CH}_{2} \mathrm{OH}$<smiles>COC(=O)[C@H]1c2c(oc3cc(CO)cc(O)c3c2=O)CC[C@H]1O</smiles>
3<smiles>COC(=O)C1c2c(oc3cc(CO)cc(O)c3c2=O)CC(O)C1O</smiles>
$1 \beta, 2 \beta, 3 \beta-$<smiles>COC(=O)[C@H]1c2c(oc3cc(C)cc(O)c3c2=O)C[C@@H](O)[C@@H]1O</smiles>

4

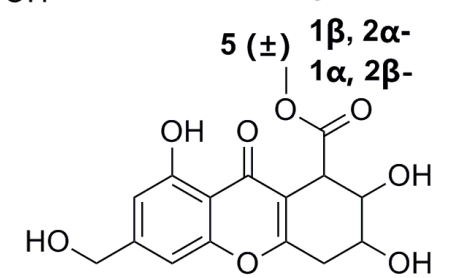

$7( \pm) \begin{aligned} & 1 \beta, 2 \beta, 3 \alpha- \\ & 1 \alpha, 2 \alpha, 3 \beta-\end{aligned}$<smiles>COC(=O)C1c2c(oc3cc(CO)cc(O)c3c2=O)CCC1O</smiles>

$5( \pm) 1 \beta, 2 \alpha-$<smiles>[R]C1C=Cc2oc3cc(CO)cc(O)c3c(=O)c2C1C(=O)OC</smiles>

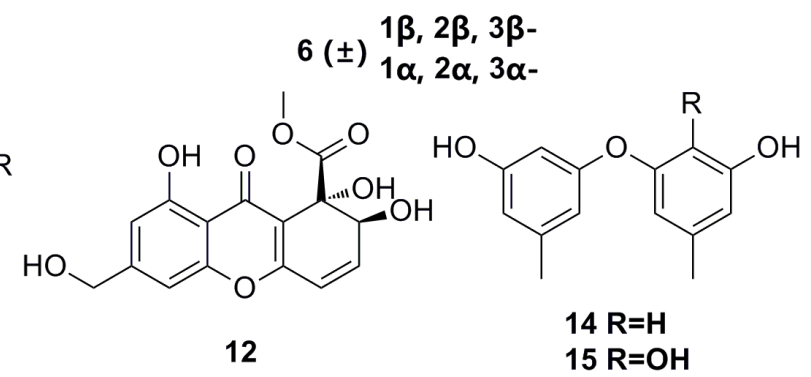
$13 \mathrm{R}=\beta-\mathrm{OH}$ $15 \mathrm{R}=\mathrm{OH}$<smiles>CC(C)CCCC(C)(O)c1ccc(C(=O)O)cc1O</smiles>
16

Figure 1. Chemical structures of compounds 1-16.

Nine new C9 polyketides, named aspiketolactonol (17), aspilactonols A-F (18-23), aspyronol (25), and epiaspinonediol (27), together with five known polyketides, (S)-2-(2'-hydroxyethyl)-4methyl- $\gamma$-butyrolactone (24), dihydroaspyrone (26), aspinotriol A (28), aspinotriol B (29), and chaetoquadrin F (30) (Figure 2), have been isolated from the secondary metabolites of Aspergillus sp. 16-02-1, which was isolated from a deep-sea sediment at a Lau Basin hydrothermal vent (depth $2255 \mathrm{~m}$, temperature $114{ }^{\circ} \mathrm{C}$ ) in the southwest of the Pacific Ocean. All of these compounds show strong cytotoxic activities against human cancer cell lines such as K562, HL-60, HeLa, and BGC-823 [42]. 
<smiles>[H][Z9]([H])(O)[C@]1(C)C=C(CC(C)=O)C(=O)O1</smiles>

17<smiles>C[C@H]1C=C(CCO)C(=O)O1</smiles>

24<smiles>C[C@H](O)CCC1=C[C@H](C)OC1=O</smiles>

18<smiles>[R]C(C1=C[C@H](O)[C@@H](C)OC1=O)[C@H](C)O</smiles>

25: $\mathrm{R}=\mathrm{OCH}_{3} ; 8 \mathrm{~S}, 9 \mathrm{R}$ 26: $\mathrm{R}=\mathrm{H}$; $9 \mathrm{~S}$<smiles>C[C@@H](O)[C@H]1C=C([C@@H](O)CO)C(=O)O1</smiles>

19: $8 S, 9 R$;

20: 8R, 9S<smiles>CC(=O)/C=C/C(=C[C@H](C)O)CO</smiles>

27<smiles>CO[C@@H](C1=C[C@@H]([C@H](C)O)OC1=O)[C@@](C)(O)CO</smiles>

21<smiles>C[C@H](O)/C=C/C(=C\[C@H](C)O)CO</smiles><smiles>[R][C@H](O)[C@H](C)C=C1C(=O)O[C@@H]1CC(C)O</smiles>

22: $9 \mathrm{R}$

23: $9 S$<smiles>Cc1c(O)cc(C[C@H](C)O)oc1=O</smiles>

Figure 2. Chemical structures of compounds 17-30.

Five new nitrogen-containing sorbicillinoids, named sorbicillamines A-E (31-36) (Figure 3), have been isolated from an agitated culture of a deep-sea fungus Penicillium sp. F23-2. The structures of 31 to 36, including absolute configurations, were determined based on MS, NMR, and circular dichroism (CD) data. Unfortunately, all these compounds show weak cytotoxicity ( $\left.\mathrm{IC}_{50}>10 \mu \mathrm{M}\right)$ against the HeLa, BEL-7402, HEK-293, HCT-116, and P388 cell lines. Moreover, the strain F23-2 is able to produce indole alkaloids and terpenoids when it is cultured under static conditions [43].
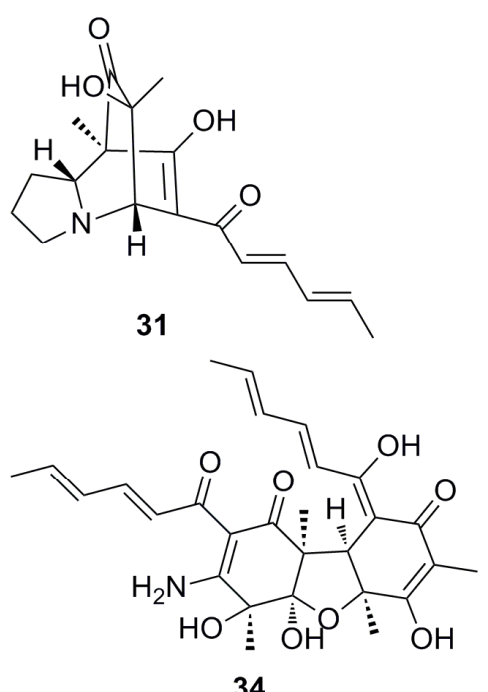

34
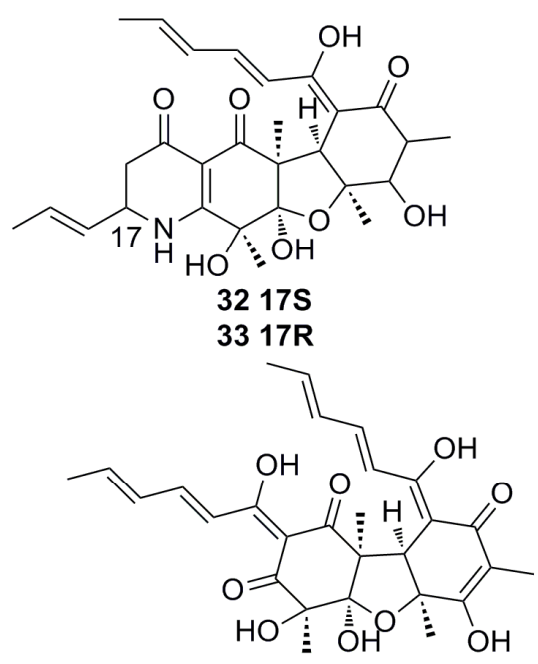

36

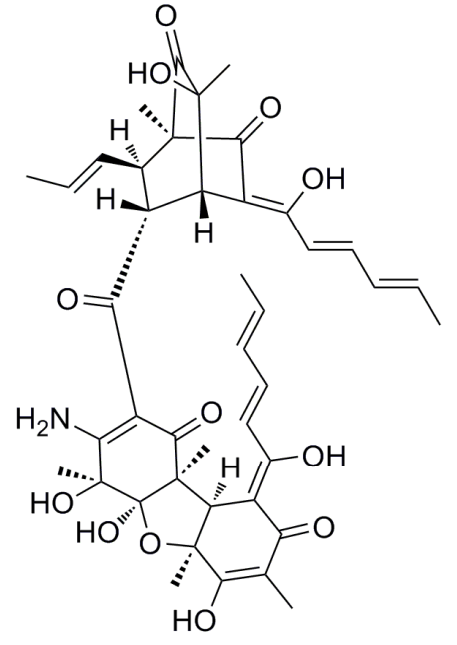

35

Figure 3. Chemical structures of compounds 31-36.

Two highly oxygenated polyketides, penilactone A (37) and B (38) (Figure 4), containing a new carbon skeleton formed from two 3,5-dimethyl-2,4-diol-acetophenone units and a $\gamma$-butyrolactone moiety, have been isolated from a fungus named Penicillium crustosum PRB-2, which was derived from deep water environments of the Antarctic Ocean. Penilactones A and B possess antipodal absolute stereochemistry and show weak antitumor activity. However, penilactone A exhibits weak cytotoxic activity against NF- $\mathrm{BB}(40 \%)$ at the concentration of $10 \mathrm{mM}$ [25].

Two new fungal hybrid polyketides, cladosin F (39) and G (40) (Figure 4), with a rare 6(3)-enamino8,10-dihydroxy-tetraketide system have been discovered from the deep-sea-derived fungus Cladosporium 
sphaerospermum 2005-01-E3, guided by the OSMAC approach. Both exhibit weak in vitro antitumor activity [44].<smiles>CC(=O)c1cc(C)c(O)c(CC23Cc4c(O)c(C(C)=O)cc(C)c4O[C@@]2(O)[C@@H](C)OC3=O)c1O</smiles>

37<smiles>CC(=O)c1cc(C)c2c(c1O)C[C@@]1(Oc3c(C)cc(C(C)=O)c(O)c3O2)C(=O)OC(CC(=O)O)[C@@]1(C)O</smiles>

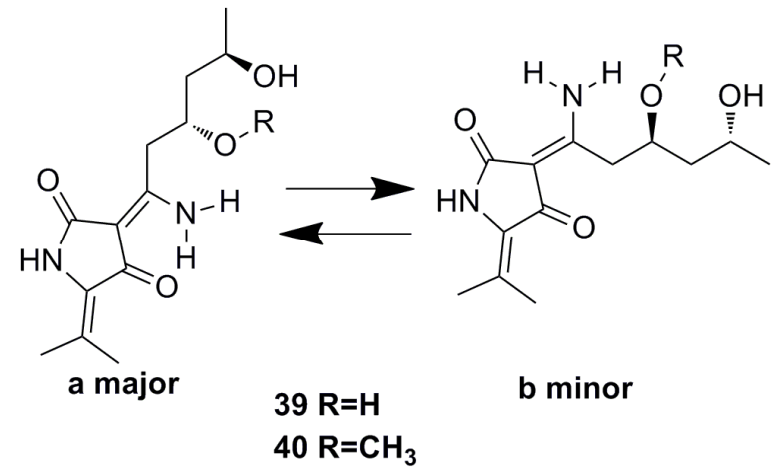

Figure 4. Chemical structures of compounds 37-40.

\subsubsection{Steroid Derivatives}

Seven secondary metabolites including 9(11)-dehydroergosterol peroxide (41), ergosterol peroxide (42),

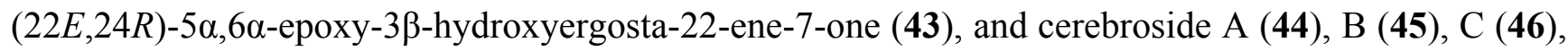
and D (47) (Figure 5) have been described by Cui et al. in 2013 from the deep-sea fungus Paecilomyces lilacinus ZBY-1. These compounds exhibit cytotoxic activity against K562, MCF-7, HL-60, and BGC-823 cells with $\mathrm{IC}_{50}$ of 22.3 to $139.0 \mu \mathrm{M}$ [45].

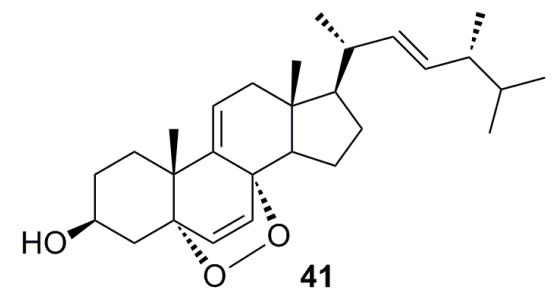

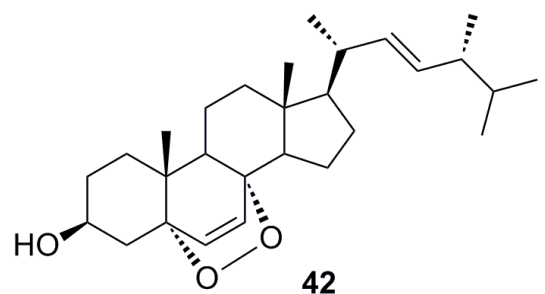

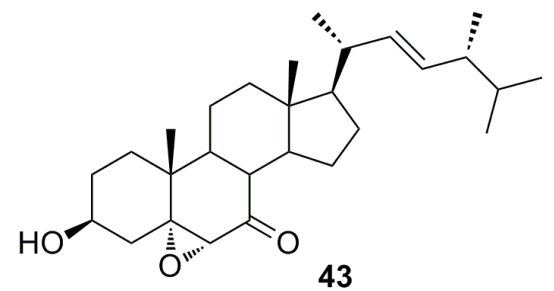

43

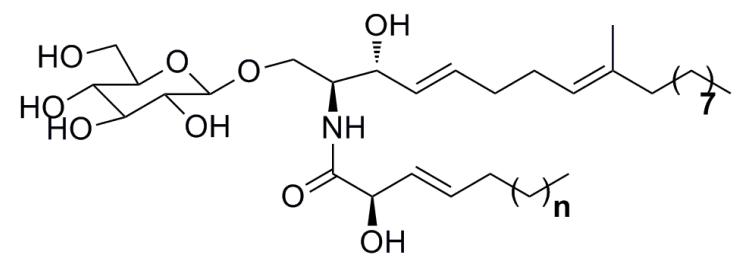

$44 n=10$

$45 n=12$

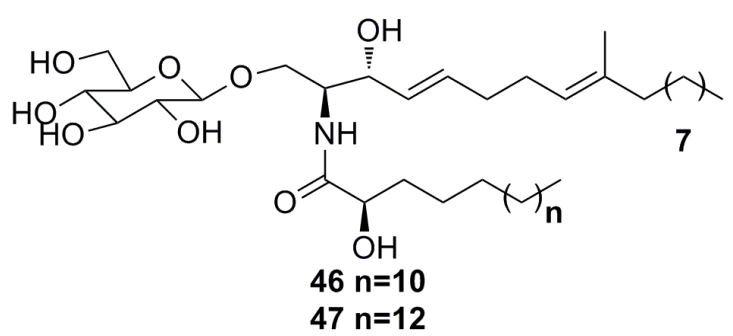

Figure 5. Chemical structures of compounds 41-47.

Li et al. (2012) reported two sterols, sterolic acid (48) and sterol (49) (Figure 6), which were isolated from the crude extract of the deep-sea fungus Penicillium sp. metabolites. Compounds $\mathbf{4 8}$ and $\mathbf{4 9}$ show slight cytotoxic effects against MCF-7 cells and A549 cells [46].

Compounds ergosterol (50) and ergosterol peroxide (51) (Figure 6) have been isolated from the cultures of the deep-sea fungus Penicillium sp. F00120, which was collected from the northern South China Sea at a depth of $1300 \mathrm{~m}$ [47]. Compound $\mathbf{5 1}$ also has been isolated from the deep-sea-derived 
fungus Aspergillus sp. CXCTD-06-6a [48]. Both compounds show good cytotoxicity $(27.2 \%-31.5 \%)$ against the HeLa cell line at $10 \mu \mathrm{M}$ [47].

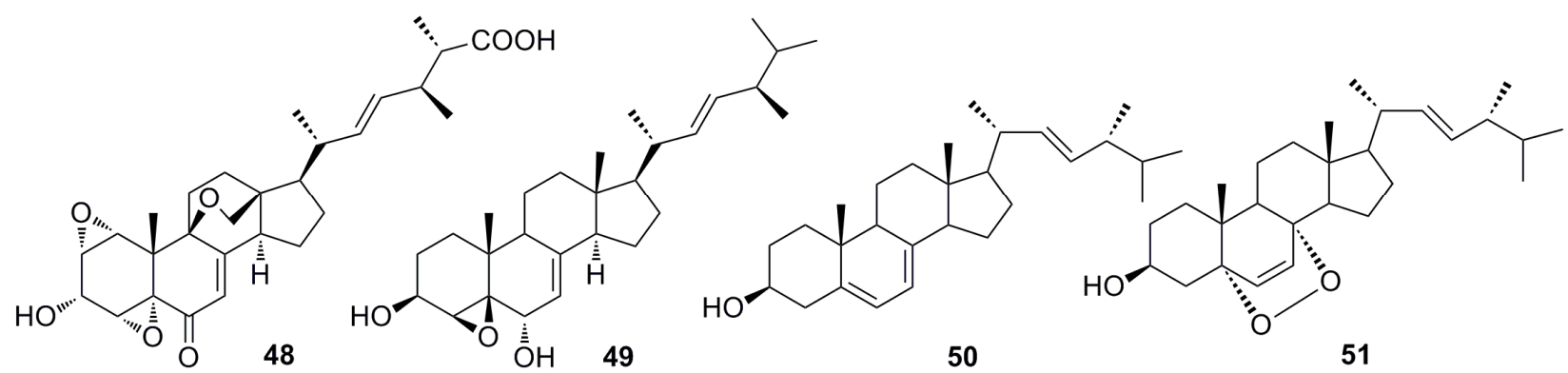

Figure 6. Chemical structures of compounds 48-51.

(17R)-17-Methylincistererol (52) and cerevisterol (53) (Figure 7) were isolated from the deep-sea fungus Aspergillus sydowi by a bioassay-guided method. Compound $\mathbf{5 2}$ has been considered as a highly degraded product of sterol, while compound $\mathbf{5 3}$ is a common metabolite of fungi. Both exhibit cytotoxicity [49]. Shang et al. (2012) [50] also reported compound 53 together with compound 54 (Figure 7), which was isolated from the deep-sea fungus Penicillium commune SD-118. All of them show a slight cytotoxicity against MCF-7 [50].

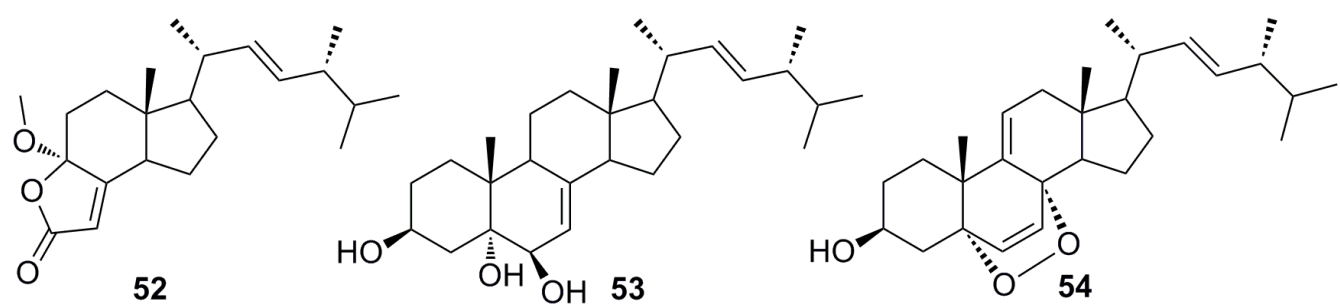

Figure 7. Chemical structures of compounds 52-54.

\subsubsection{Indole Derivatives}

Three new prenylated indole alkaloids, including two $\beta$-carbolines, penipaline A (55) and B (56), and one indole carbaldehyde derivative, penipaline C (57), as well as two known indole-derived analogs $(\mathbf{5 8 , 5 9})$ (Figure 8), have been isolated from the metabolites of the deep-sea fungus Penicillium paneum SD-44, which was cultivated in a 500-L bioreactor. All these metabolites show cytotoxicity against A549 (IC50: 20.4-21.5 $\mu \mathrm{M}$ ) and HCT-116 (IC50: 14.9-18.5 $\mu \mathrm{M}$ ) cell lines [51].

5-Chlorosclerotiamide (60) and 10-epi-sclerotiamide (61) (Figure 8) are the secondary metabolites of the deep-sea fungus Aspergillus westerdijkiae DFFSCS013, which show excellent cytotoxicity against K562 cell line with IC50 of $44 \mu \mathrm{M}$ and $53 \mu \mathrm{M}$, respectively [52]. 


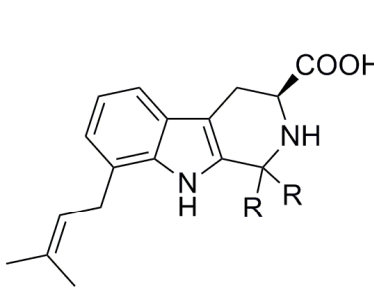

$55 \mathrm{R}=\mathrm{H}$

$56 \mathrm{R}=\mathrm{Me}$

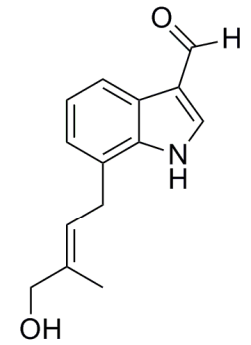

57

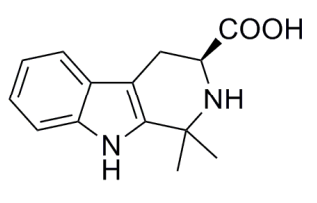

58

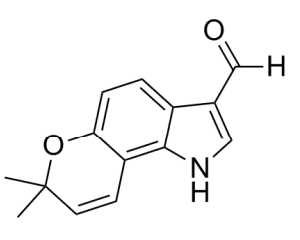

59

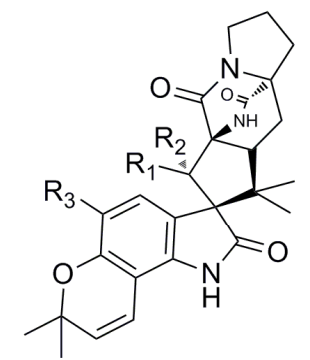

$60 \mathrm{R}_{1}=\mathrm{H}, \mathrm{R}_{2}=\mathrm{OH}, \mathrm{R}_{3}=\mathrm{Cl}$ $61 \mathrm{R}_{1}=\mathrm{OH}, \mathrm{R}_{2}=\mathrm{H}, \mathrm{R}_{3}=\mathrm{H}$

Figure 8. Chemical structures of compounds 55-61.

\subsubsection{Sesquiterpenoids}

Chemical investigation of the Penicillium sp. PR19 N-1 isolated from the Antarctic deep-sea has yielded five new eremophilane-type sesquiterpenes (62-66) (Figure 9). These compounds show strong cytotoxicity against HL-60 cells (IC50: 28.3-45.8 $\mu \mathrm{M}$ ) and the A-549 cells (IC50: 5.2-82.8 $\mu \mathrm{M}$ ) [53]. In 2013, Wu et al. [24] isolated a new chloro-trinoreremophilane sesquiterpene 67, three new chlorinated eremophilane sesquiterpenes (68-70), and a known compound, eremofortine C (71) (Figure 9), from the same strain, PR19N-1. They found that all the compounds (67-71) exhibit cytotoxic activity against HL-60 and A549 cell lines. Particularly, compound 67 shows great cytotoxicity against HL-60 and A549 cell lines with $\mathrm{IC}_{50}$ of 11.8 and $12.2 \mu \mathrm{M}$, respectively [24].

In 2010, Chen et al. reported a new sesquiterpene, hydroquinone (72) (Figure 9), which was isolated from the metabolites of the deep-sea fungus Phialocephala sp. This compound displays strong cytotoxic activity against $\mathrm{P} 388$ and $\mathrm{K} 562$ cells with $\mathrm{IC}_{50}$ of $0.16 \mu \mathrm{M}$ and $0.05 \mu \mathrm{M}$, respectively [54].<smiles>C=C(C)[C@@H]1C[C@]2(C)C(=C[C@H](O)C[C@H]2C)C[C@H]1O</smiles><smiles>CC(=O)O[C@H]1C=C(Cl)C2=CC(=O)C(O)=C[C@@]2(C)[C@H]1C[18O]</smiles><smiles>CO[C@]12C=C3C(Cl)=C(O)[C@H](OC(C)=O)[C@H](C)[C@@]3(C)C[C@]13OC3(C)CO2</smiles>

70<smiles>[R]C1C[C@]2(C)C(=C[C@H]1O)C=C[C@H](O)[C@H]2C</smiles>

63<smiles>C[C@H]1[C@@H](O)C=C(Cl)C2=CC(=O)[C@]3(C[C@@]21C)O[C@@]3(C)CO</smiles>

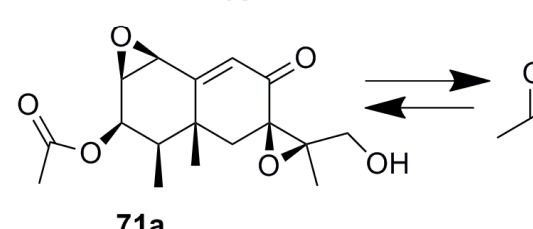

71<smiles>CC1=C2C[C@]3(C)C(=CC(=O)[C@@H](O)[C@@H]3C)C=C2OC1=O</smiles>

65<smiles>CC(C)=C1C[C@]2(C)[C@H](C)C[C@@H](O)C(C)(C)[C@@]2(C)CC1=O</smiles>

69<smiles>C[C@H]1[C@H](OC(=O)O)C2OC2C2=C[C@]3(O)OCC4(C)O[C@]43C[C@@]21C</smiles>

71b

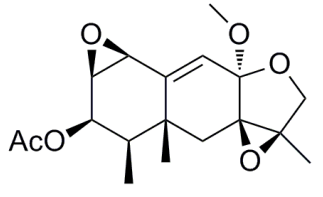

66<smiles>O=Cc1cc(O)c(I)cc1O</smiles>

72

Figure 9. Chemical structures of compounds 62-72.

\subsubsection{Alkaloid Compounds}

Shang et al. (2012) reported three alkaloids (73-75) (Figure 10) that were isolated from the deep-sea fungus Penicillium commune SD-118. These alkaloid compounds show potent cytotoxicity against the 
DU145 cell line with IC50 of 4.3-5.0 $\mu \mathrm{M}$. Moreover, compound 75 shows moderate cytotoxicity toward the HepG2, NCIH460, HeLa, and MDA-MB-231 cell lines with IC50 of 0.03, 0.05, 0.05, and 0.03 mM, respectively [50].<smiles>COC(=O)CC(=O)NCCc1c[nH]c2ccccc12</smiles>

73

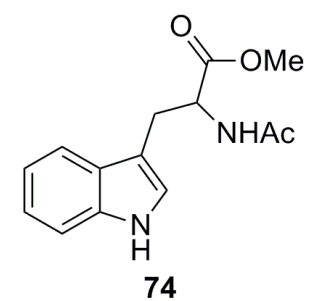

74

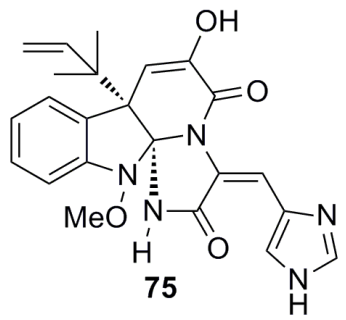

Figure 10. Chemical structures of compounds 73-75.

\subsubsection{Aromatic Compounds}

Five new anthranilic acid derivatives, penipacids A-E (76-80), together with one known analogue (81) (Figure 11), which was previously synthesized, have been obtained from the ethyl acetate extract of the deep-sea fungus Penicillium paneum SD-44. These compounds exhibit cytotoxic activity against the RKO cell line ( $\mathrm{IC}_{50}$ : 8.4-9.7 $\mu \mathrm{M}$ ). Especially, compound 81 displays remarkable cytotoxicity against the HeLa cell line with an $\mathrm{IC}_{50}$ of $6.6 \mu \mathrm{M}$ [55].<smiles>[R]C(C)(C)CN=C(C)Nc1ccccc1C(=O)O</smiles>

76: $\mathrm{R}=\mathrm{OH}$

77: $\mathrm{R}=\mathrm{OMe}$<smiles>[R]OC(=O)/N=C(\C)Nc1ccccc1C(=O)O</smiles>

78: $\mathrm{R}=\mathrm{H}$

79: $\mathrm{R}=\mathrm{Me}$<smiles>O=C(O)c1ccccc1/N=C/c1ccco1</smiles>

80<smiles>CC(=O)/C(C)=N/c1ccccc1C(=O)O</smiles>

81

Figure 11. Chemical structures of compounds 76-81.

A compound (2'S)-4-methoxy-3-(2'-methyl-3'-hydroxy) propionyl-methyl benzoate (82) (Figure 12) has been isolated from the metabolites of the deep-sea fungus Aspergillus sp. 16-02-1. This compound possesses $34.5 \%, 25.2 \%, 3.2 \%$, and $15.5 \%$ cytotoxicity against human cancer cell lines K562, HL-60, HeLa, and BGC-823, respectively, at $100 \mu \mathrm{g} / \mathrm{mL}$ [56].

A secondary metabolite of 5-hydroxy-2-methoxy benzoic acid (83) (Figure 12) was isolated from the deep-sea fungus Aspergillus sp. CXCTD-06-6a, which shows $7.29 \%$ of cytotoxic activity against the HeLa cell line at $1.68 \mu \mathrm{g} / \mathrm{mL}$ [48].

An aromatic compound (84) (Figure 12) has been isolated from the metabolites of the deep-sea sediment-derived Penicillium commune SD-118. It exhibits moderate cytotoxicity against the SW1990 cell line with $\mathrm{IC}_{50}$ of $0.11 \mathrm{mM}[50]$. 
<smiles>COC(=O)c1ccc(OC)c(OC(=O)C(C)CO)c1</smiles><smiles>COc1ccc(O)cc1C(=O)O</smiles>

83<smiles>CC(O)c1nc2ccccc2c(=O)[nH]1</smiles>

84

Figure 12. Chemical structures of compounds 82-84.

A new methyl 2-(4-((2-hydroxy-3-methylbut-3-en-1-yl)oxy)phenyl) acetate (85), together with five known compounds (86-90) (Figure 13), has been isolated from the culture of the deep-sea fungus Aspergillus westerdijkiae SCSIO 05233. All of these display weak cytotoxic activities. Compound 89 displays weak antiproliferation activities towards K562 and promyelocytic HL-6 (IC50: 25.8-44.9 mM), while compound 90 shows strong antifouling activity with EC50 of $27.5 \mathrm{mM}$ [57].<smiles>C=C(C)C(O)COc1ccc(CC(=O)OC)cc1</smiles><smiles>CC1(C)Cc2cccc(O)c2C(=O)O1</smiles>

86<smiles>CC1(O)Cc2cccc(O)c2C(=O)O1</smiles>

87<smiles>CC1OC(=O)c2c(O)cccc2C1O</smiles>

88<smiles>CC1NC(=O)c2ccccc2CC2C(=O)c3cccc(O)c3N=C12</smiles>

89<smiles>C[C@H]1NC(=O)c2ccccc2CC2C(=O)c3cccc(O)c3N=C21</smiles>

90

Figure 13. Chemical structures of compounds 85-90.

\subsubsection{Fatty Acids}

Four fatty acid compounds, methyl myristate (91), methyl linoleate (92), linoleate (93), and oleinic acid (94) (Figure 14), have been isolated from the metabolites of the deep-sea fungus Paecilomyces lilacinus ZBY-1. All of them exhibit 30\%-80\% cytotoxicity against human cancer cell lines K562, MCF-7, HL-60, and BGC-823 at $100 \mathrm{mg} / \mathrm{L}$ [58].
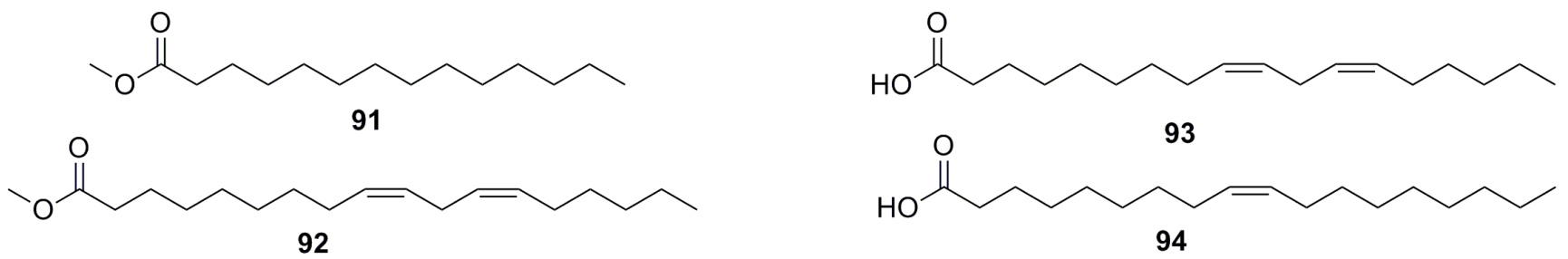

Figure 14. Chemical structures of compounds 91-94.

\subsubsection{Pyrone Analogues}

Two new compounds, 2,3,5-trimethyl-6-(3-oxobutan-2-yl)-4H-pyran-4-one (95) and (2R)-2,3dihydro-7-hydroxy-6,8-dimethyl-2-[(E)-prop-1-enyl]chromen-4-one (96), together with six known compounds (97-100) (Figure 15), were isolated from the deep-sea fungus Aspergillus sydowi by a 
bioassay-guided method. All these compounds exhibit various degrees of cytotoxicity. Compounds 96 and $\mathbf{1 0 0}$ show strong cytotoxicity against P388 cells with $\mathrm{IC}_{50}$ of 0.14 and $0.59 \mu \mathrm{M}$, respectively [49].<smiles>C/C=C/C1CC(=O)c2cc(C)c(O)c(C)c2O1</smiles>

Figure 15. Chemical structures of compounds 95-100.

\subsubsection{Sorbicillin Derivative}

A novel sorbicillin trimer, trisorbicillinone A (101) (Figure 16), was isolated from the deep-sea fungus Phialocephala sp. FL30r. Trisorbicillinone A shows cytotoxicity against P388 and HL60 cells with $\mathrm{IC}_{50}$ of 9.1 and $3.1 \mu \mathrm{M}$, respectively [59].

Two new bisorbicillinoids, named oxosorbiquinol (102) and dihydrooxosorbiquinol (103) (Figure 16), have been isolated from the deep-sea fungus Phialocephala sp. Both of them show cytotoxicity (IC50: 8.9-103.5 $\mu \mathrm{M}$ ) against P388, A549, HL60, BEL-7402, and K562 cell lines [60].
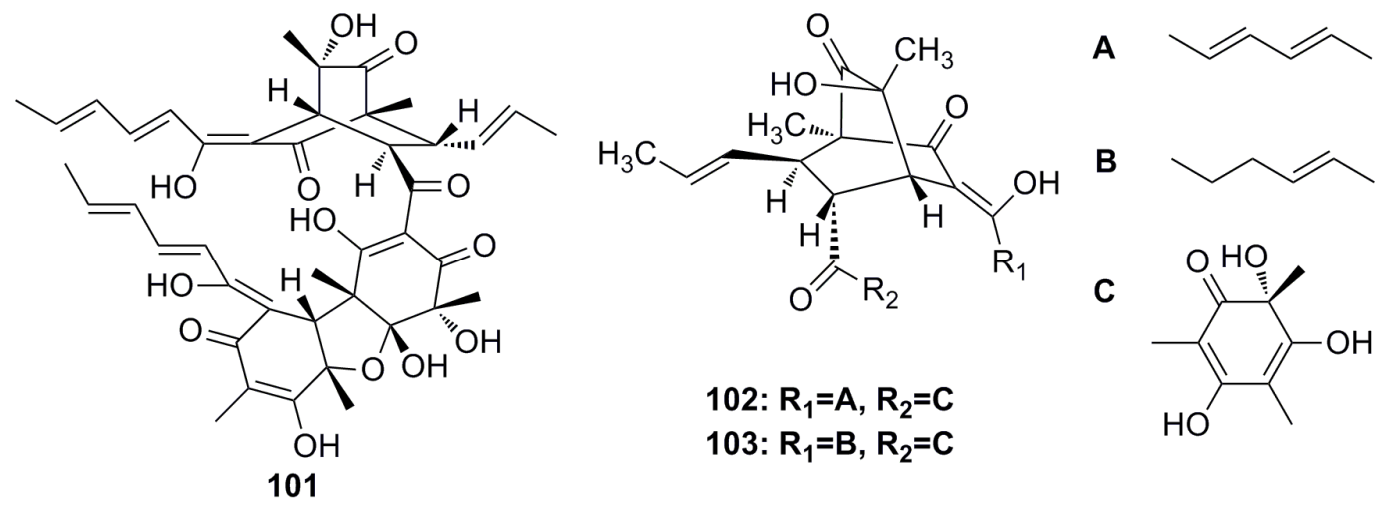

Figure 16. Chemical structures of compounds 101-103.

\subsubsection{Breviane Derivative}

Three new breviane spiroditerpenoids, breviones I-K (104-106), and the known breviones (107-110) (Figure 17) have been isolated from the crude extract of the deep-sea fungus Penicillium sp. and display strong cytotoxic effects against MCF-7 cells ( $\mathrm{IC}_{50}$ : 7.44-28.4 $\mu \mathrm{M}$ ). Compound 106 exhibits cytotoxic activity against A549 cells with $\mathrm{IC}_{50}$ of $32.5 \mu \mathrm{M}$ [46]. Similar compounds, Breviones F-H (111-113) (Figure 17), have been isolated from the same fungal species by Li et al. (2009) [61]. These compounds (111-113) show $25.2 \%-44.9 \%$ cytotoxicity against $\mathrm{HeLa}$ at $10 \mu \mathrm{g} / \mathrm{mL}$. Particularly, compound 111 displays a very strong cytotoxicity to HIV-1 replication in C8166 cells with an EC50 of $14.7 \mu \mathrm{M}$ [61]. 


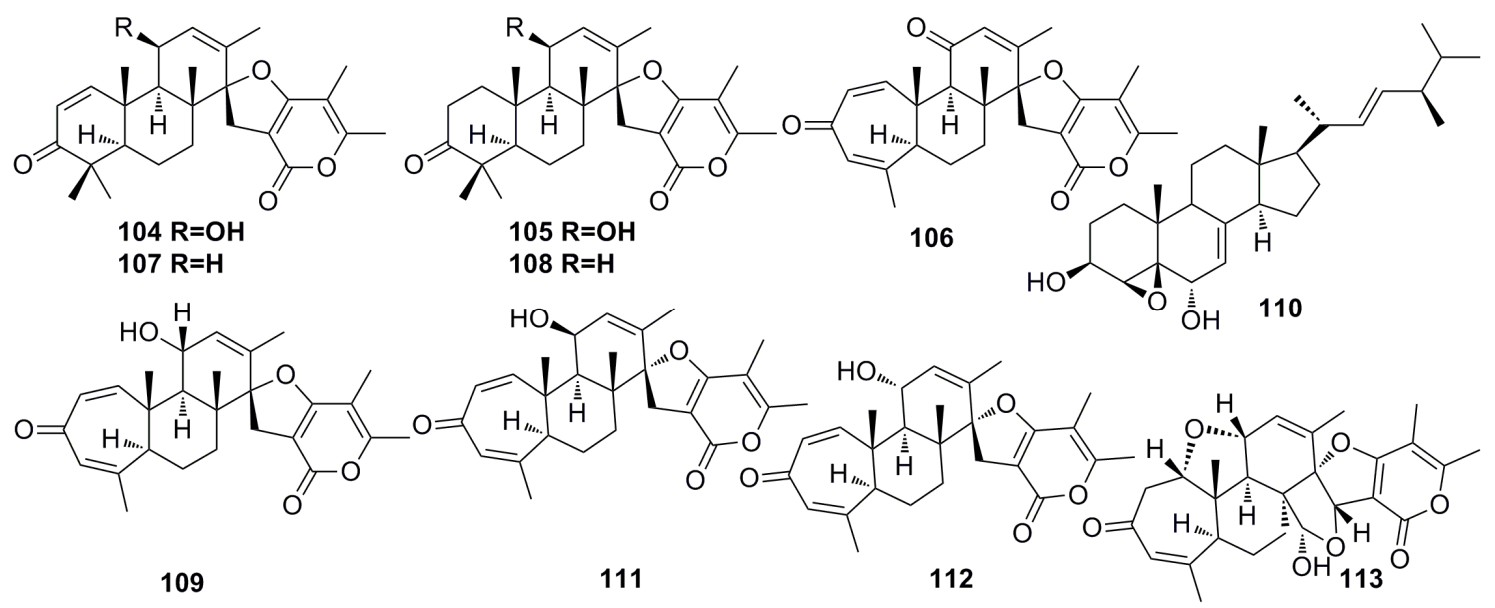

Figure 17. Chemical structures of compounds 104-113.

\subsubsection{Compounds Containing Amino Acid Structure}

Six metabolites, cyclo(D-Pro-D-Phe) (114), cyclo(D-Tyr-D-Pro) (115), phenethyl 5-oxo-L-prolinate (116), cyclo(L-Ile-L-Pro) (117), cyclo(L-Leu-L-Pro) (118), and 3 $\beta, 5 \alpha, 9 \alpha$-trihydroxy-(22E,24R)-ergosta7,22-dien-6-one (119) (Figure 18), have been isolated from the secondary metabolites of a mutated deep-sea fungal strain of Aspergillus versicolor ZBY-3. These compounds show certain cytotoxicity against $\mathrm{K} 562$ cells at a concentration of $100 \mu \mathrm{g} / \mathrm{mL}$ [62].<smiles>[R]c1ccc(C[C@H]2NC(=O)[C@H]3CCCN3C2=O)cc1</smiles>

114: $\mathrm{R}=\mathrm{H}$

115: $\mathrm{R}=\mathrm{OH}$

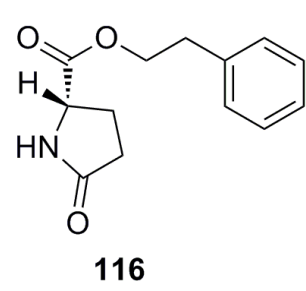

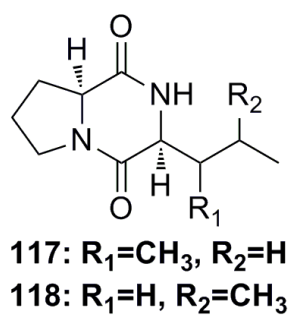

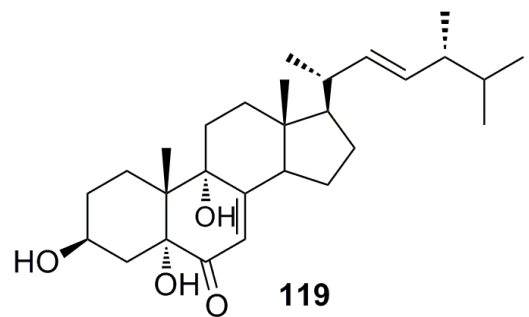

Figure 18. Chemical structures of compounds 114-119.

\subsubsection{Other Compounds}

A novel cyclopentenone, trichoderone (120), and a known compound, cholesta-7,22-diene-3b, 5a,6b-triol (121) (Figure 19), were identified from the deep-sea fungus Trichoderma sp., which was isolated from the deep-sea sediment of the South China Sea. Compound $\mathbf{1 2 0}$ shows more than 80\% cytotoxicity against A549 and NCIH460 cancer cell lines. The selectivity index for $\mathbf{1 2 0}$ was greater than 100. The two compounds also act as enzyme inhibitors against HIV protease and Taq DNA polymerase [18]. 


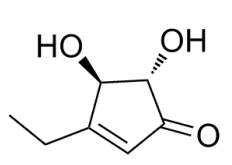

120

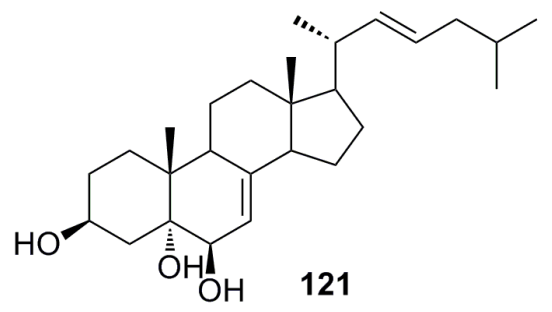

Figure 19. Chemical structures of compounds 120 and 121.

New aspergillic acid (122), ferrineoaspergillin (123), aflatoxin (124), and (11S)-hydroxyl aspergillic acid (125) (Figure 20) have been isolated from the deep-sea fungus Aspergillus sp. 16-02-1. These compounds possess certain cytotoxicity against human cancer cell lines K562 (33.6\%-43.6\%), HL-60 (24.1\%-53.3\%), HeLa (18.8\%-45.4\%), and BGC-823 (36.2\%-51.2\%) at the concentration of $100 \mu \mathrm{g} / \mathrm{mL}[56]$.

A known antibacterial compound, xanthocillin X (126) (Figure 20), was isolated for the first time from the deep-sea fungus Penicillium commune SD-118. This compound displays not only remarkable antimicrobial activity against Staphylococcus aureus and Escherichia coli with MIC of 1-64 $\mu \mathrm{g} / \mathrm{mL}$, but also significant cytotoxicity against MCF-7, HepG2, H460, HeLa, DU145, and MDA-MB-231 cell lines (IC50: 7-22 $\mu \mathrm{g} / \mathrm{mL})[50,63]$.

One new sesquiterpene quinone, named penicilliumin A (127) (Figure 20), was isolated from the deep-sea fungus Penicillium sp. F00120. It inhibits in vitro proliferation of mouse melanoma (B16), human melanoma (A375), and human cervical carcinoma (HeLa) cell lines with IC50 of 0.08, 0.06, and $0.12 \mathrm{mM}$, respectively [47].
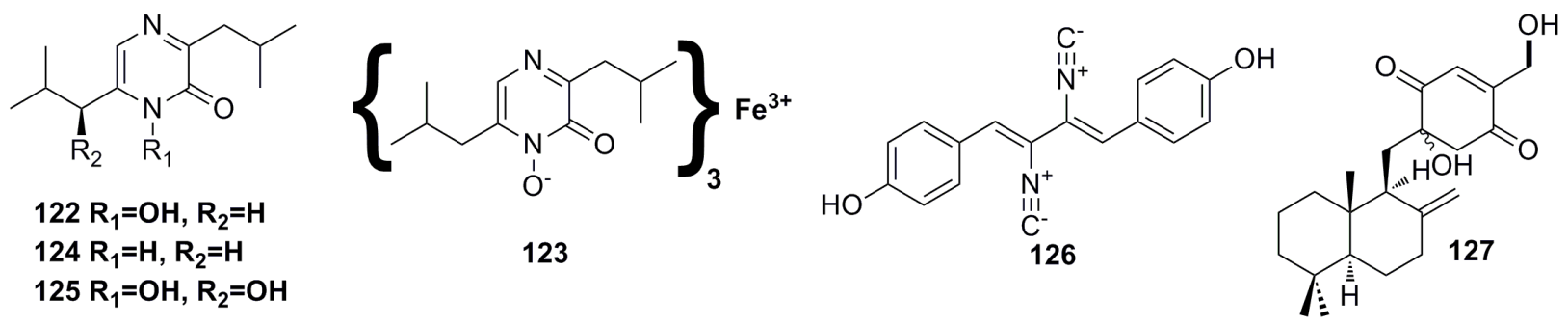

Figure 20. Chemical structures of compounds 122-127.

Three new sterigmatocystin derivatives, oxisterigmatocystin A (128), oxisterigmatocystin B (129), and oxisterigmatocystin C (130), together with one known compound, 5-methoxysterigmatocystin (131) (Figure 21), have been isolated from the deep-sea fungus Aspergillus versicolor. The structures of the new compounds were elucidated by spectroscopic methods. All the compounds show cytotoxic activity against A549 and HL-60 cell lines, and compound 131 is the best with $\mathrm{IC}_{50}$ of $3.86 \mathrm{mM}$ and $5.32 \mathrm{mM}$, respectively [64]. 

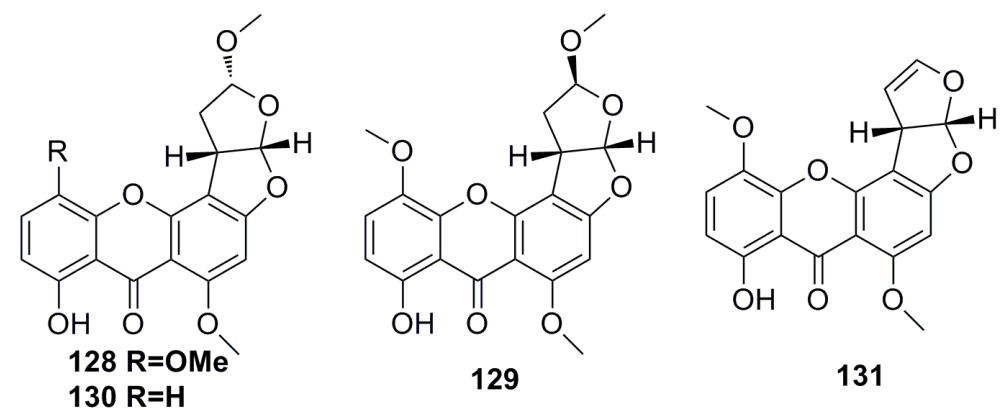

Figure 21. Chemical structures of compounds 128-131.

Seven gliotoxin-related compounds including two new metabolites, bis(dethio)-10a-methylthio3a-deoxy-3,3a-didehydrogliotoxin (132) and 6-deoxy-5a,6-didehydrogliotoxin (133), and five known metabolites (134-138) (Figure 22) have been isolated from the fungus Penicillium sp. strain JMF034, which was obtained from the deep-sea sediments of Suruga Bay, Japan. All these types of compounds exhibit significant cytotoxic activity against P388 ( $\mathrm{IC}_{50}$ : 0.02-3.40 $\left.\mu \mathrm{M}\right)$, whereas compounds 136-138 containing a disulfide or tetrasulfide bond show potential inhibitory activity against histone methyltransferase (HMT) G9a (IC50: 2.1-6.4 $\mu \mathrm{M})$ [65].

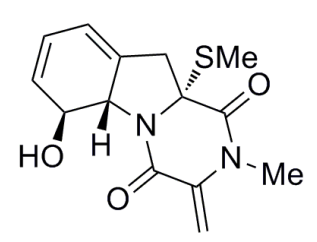

132

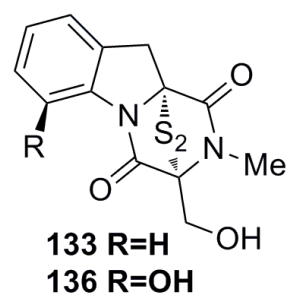

$136 \mathrm{R}=\mathrm{OH}$

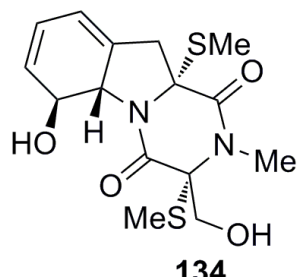

134
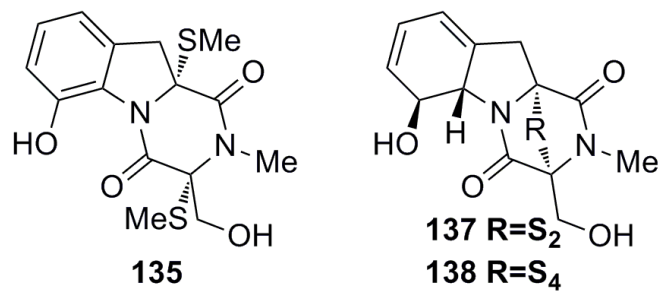

Figure 22. Chemical structures of compounds 132-138.

\subsection{Antibacterial}

Antimicrobials are the most important drugs to protect human beings from infective diseases. Deep-sea fungi are one of the potential pools for screening antimicrobial metabolites, which can be developed into new drugs.

\subsubsection{Prenylxanthones}

Four new prenylxanthones, emerixanthones A-D (139-143), together with six known analogues (144-148) (Figure 23), were isolated from the culture of the deep-sea fungus Emericella sp. SCSIO 05240. All of them show weak growth inhibition against bacteria. The inhibition zone of compounds $\mathbf{1 3 9}$ and 141 against Escherichia coli (ATCC 29922), Klebsiella pneumonia (ATCC 13883), Staphylococcus aureus (ATCC 29213), Enterococcus faecalis (ATCC 29212), Acinetobacter baumanii (ATCC 19606), and Aeromonas hydrophila (ATCC 7966) is 1-3 mm in diameter. Moreover, compound 143 displays broad antifungal activities (3-4 mm in diameter) against Fusarium sp., Penicillium sp., Aspergillus niger, Rhizoctonia solani, Fusarium oxysporium f. sp. niveum, and Fusarium oxysporium f. sp. cucumeris [8]. 
<smiles>C=C(C)[C@H]1CCc2c(C)cc3oc4c(C)ccc(O)c4c(=O)c3c2[C@H]1O</smiles>

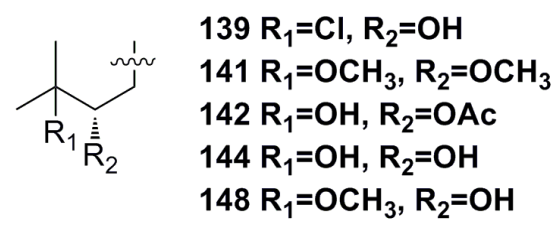<smiles>C=C(C)[C@H](O)CCCCCC</smiles><smiles>CC(O)C(C)(C)C</smiles>

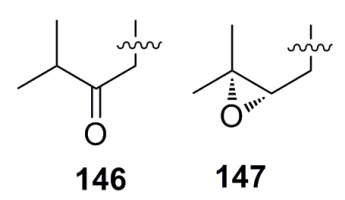

Figure 23. Chemical structures of compounds 139-148.

\subsubsection{Depsidone-Based Analogues}

Fifteen new depsidone-based analogues, named spiromastixones A-O (149-163) (Figure 24), have been isolated from the fermentation broth of the deep-sea fungus Spiromastix sp. These compounds exhibit significant growth inhibition (MIC: $0.1-8.0 \mu \mathrm{g} / \mathrm{mL}$ ) against Gram-positive bacteria including Staphylococcus aureus, Bacillus thuringiensis, and Bacillus subtilis. In addition, compounds 154-158 display potential inhibitory effects on methicillin-resistant bacterial strains of Staphylococcus aureus (MRSA) and Staphylococcus epidermidis (MRSE). Moreover, compound 158 inhibits the growth of the vancomycin-resistant bacteria of Enterococcus faecalis and Enterococcus faecium (VRE) [66].

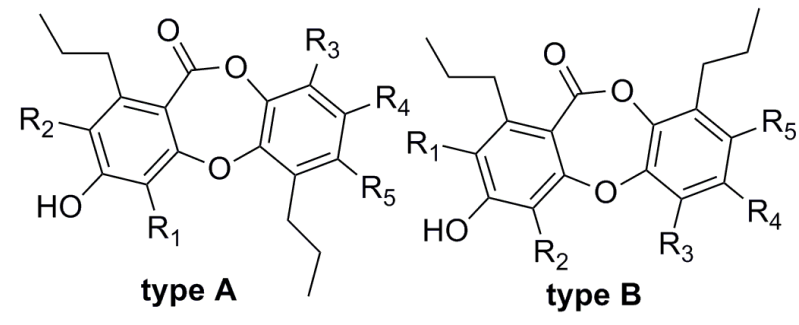

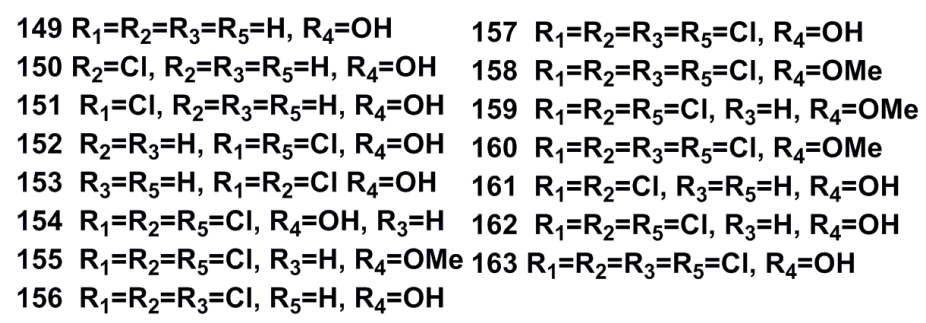

Figure 24. Chemical structures of compounds 149-163.

\subsubsection{Triple Benzene Compound}

Liu et al. (2013) [67] have reported a compound (164) (Figure 25) that was isolated from the deep-sea fungus Aspergillus candidus and possesses broad and high antibacterial activity (inhibition: 83.9\%-100\%) against Staphylococcus aureus, Bacillus subtilis, Vibrio sp. 385, Vibrio sp. 333, and Vibrio sp. 1758 [67].<smiles>COc1cc(-c2ccc(O)cc2)c(OC)c(O)c1-c1ccc(O)cc1</smiles>

Figure 25. Chemical structure of compound 164.

\subsubsection{Citromycetin Analogue}

A new citromycetin analogue, diorcinol (165) (Figure 26), has been isolated from the metabolites of Ascomycota sp. Ind19F07, which was collected from the deep-sea sediment in the Indian Ocean. 
Based on in vitro tests, compound 165 shows strong antibacterial activity against both Gram-positive and -negative bacteria such as Acinetobacter baumanii, Escherichia coli, Enterococcus faecalis, and Staphylococcus aureus [68].<smiles>Cc1cc(O)cc(Oc2cc(C)cc(O)c2)c1</smiles>

165

Figure 26. Chemical structure of compound 165.

\subsubsection{Other Compounds}

Recently, Zhang et al. (2014) [23] have evaluated the antimicrobial activities of the secondary metabolites produced by eight novel deep-sea-derived fungal species, Acremonium implicatum DFFSCS001 (AI001), Aspergillus westerdijkiae DFFSCS013 (AW013), Alternaria tenuissima DFFSCS003 (AT003), Cladosporium cladosporioides DFFSCS016 (CC016), Cladosporium sphaerospermum DFFSCS019 (CS019), Engyodontium album DFFSCS021 (EA021), Geomyces vinaceus DFFSCS022 (GV022), and Tritirachium sp. DFFSCS034 (TS034). These fungal species were isolated from sediments of the South China Sea [23], and almost all the ethyl acetate extracts of the fungal species show strong antibacterial activity against two larval-settlement-inducing bacteria Loktanella hongkongensis and Micrococcus luteus, and one marine pathogenic bacterium. Based on bioassay-guided isolation technique, they have isolated five compounds (166-170) (Figure 27) from the extract of Aspergillus westerdijkiae DFFSCS013 that show antifouling activity against Bugula neritina larval settlement with an $\mathrm{EC}_{50}$ of $6.4-34.9 \mu \mathrm{g} / \mathrm{mL}[25]$.
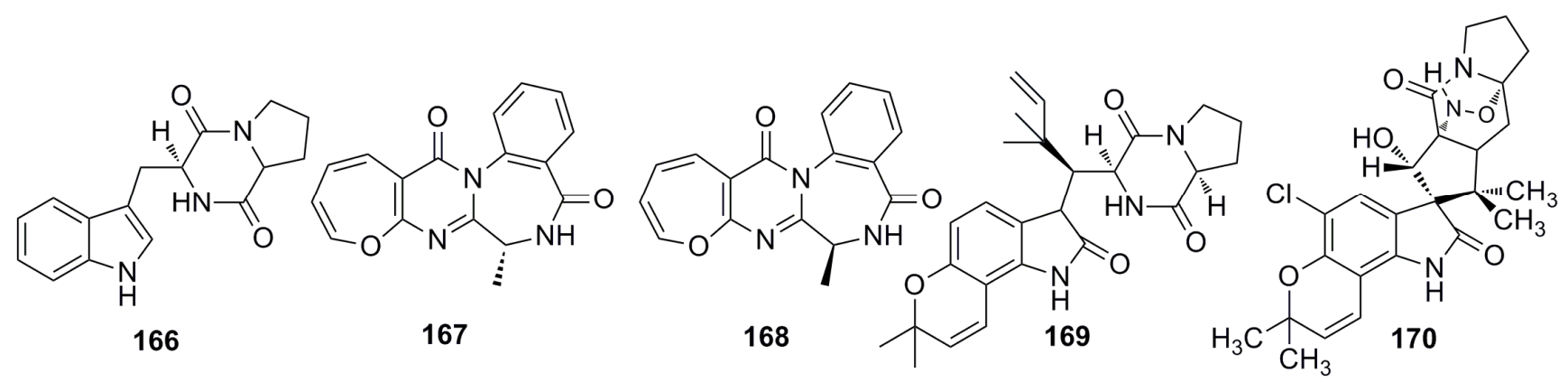

Figure 27. Chemical structures of compounds 166-170.

\subsection{Antiviral}

Polyketides

Although many polyketide compounds have been identified, the compounds derived from deep-sea fungi with antiviral activity are rare. Only one fungal hybrid polyketide with a new structure, cladosin C (171) (Figure 28), has been reported from the deep-sea fungus Cladosporium 
sphaerospermum 2005-01-E3. However, this compound shows good antiviral activity against influenza A H1N1 virus with an $\mathrm{IC}_{50}$ of $276 \mu \mathrm{M}$ [9].
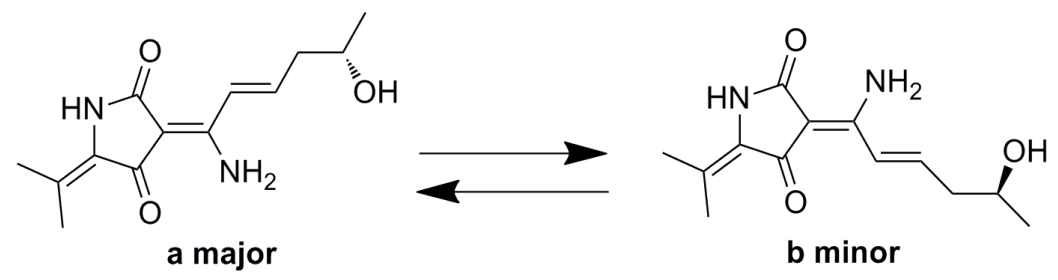

Figure 28. Chemical structure of compound 171.

\subsection{Antioxidant and Antifouling}

\subsubsection{Diketopiperazine Derivatives}

Kong et al. (2014) [69] have reported a new diketopiperazine, brevianamide W (172), and five known diketopiperazine derivatives, diketopiperazine V (173), brevianamide Q (174), brevianamide R (175), brevianamide K (176), and brevianamide E (177) (Figure 29), which were isolated from the EtOAc extract of the deep-sea fungus Aspergillus versicolor CXCTD-06-6. These compounds exhibit moderate radical scavenging activity against DPPH with clearance ratios of 55.0\% (172 and 173), 53.7\% (174), $46.2 \%$ (175), 61.4\% (176), and 19.3\% (177) at $13.9 \mu \mathrm{M}$, respectively [69].
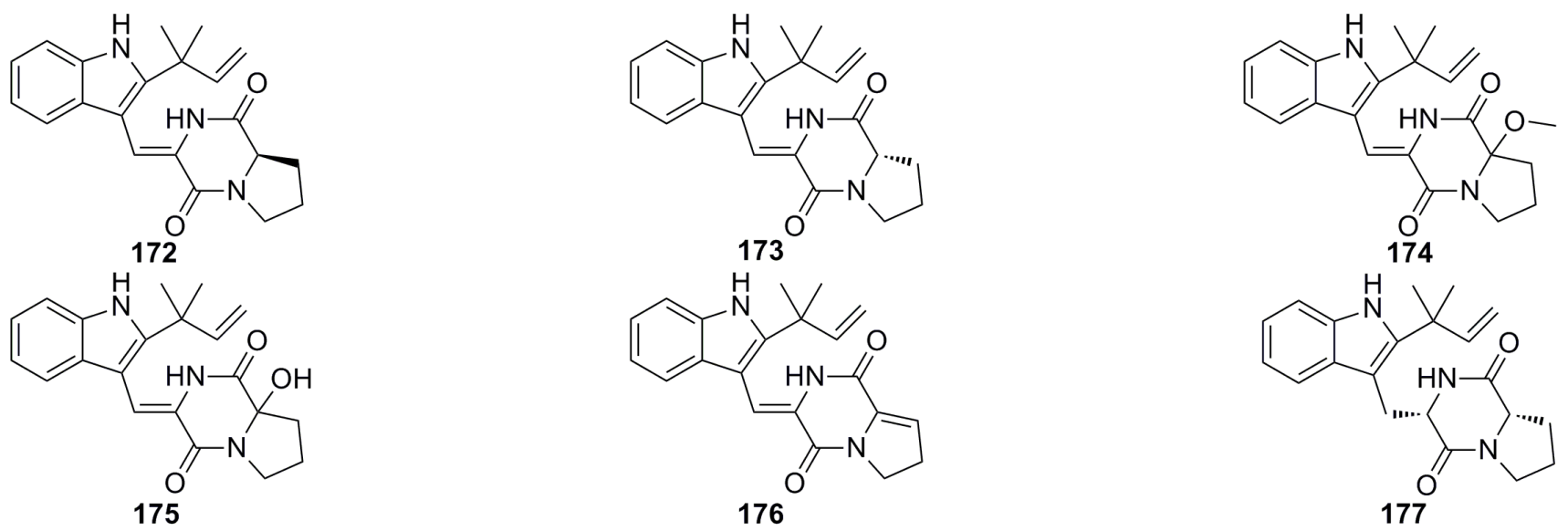

Figure 29. Chemical structures of compounds 172-177.

\subsubsection{Hydroxyphenylacetic Acid}

Compound 178 (Figure 30) has been reported from the deep-sea-derived fungus Aspergillus westerdijkiae SCSIO 05233 and shows strong antifouling activity with an EC $\mathrm{E}_{50}$ of $8.8 \mathrm{mg} / \mathrm{mL}$ [57]. 
<smiles>C[C@H]1NC(=O)c2ccccc2CC2C(=O)c3cccc(O)c3N=C21</smiles>

178

Figure 30. Chemical structure of compound 178.

\subsection{Antifungal}

One compound, $p$-hydroxyphenopyrrozin (179) (Figure 31), with a new structure has been isolated from the deep-sea fungus Chromocleista sp. and characterized on the basis of mass spectroscopy, NMR experiments, derivatization, and X-ray crystallography studies. The MIC of this compound is $25 \mu \mathrm{g} / \mathrm{mL}$ against Candida albicans [1]. In 2013, Liu et al. reported a compound (180) (Figure 31) that was isolated from the deep-sea fungus Aspergillus candidus and shows great growth inhibition against Candida albicans [67].<smiles>O=C1C(O)=C(c2ccc(O)cc2)[C@@H]2CCCN12</smiles><smiles>COc1cc(-c2ccc(O)cc2)c(O)c(OC)c1-c1ccc(O)cc1</smiles>

Figure 31. Chemical structures of compounds 179-180.

\subsection{Compounds with Other Bioactivities}

Two citrinin type compounds, phenol A acid (181) and penicitrinone A (182) (Figure 32), with anti-A $\beta$ peptide aggregation inhibition activity have been isolated from the deep-sea fungus Aspergillus sp. SCSIOW 3, which show $\mathrm{A} \beta 42$ assembling inhibition activity $(40.3 \%-72.3 \%)$ at $100 \mu \mathrm{M}[70]$.<smiles>Cc1c([C@@H](C)C(C)O)cc(O)c(C(=O)O)c1O</smiles>

181

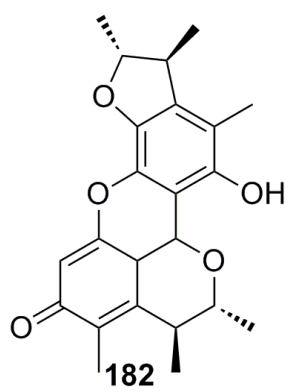

Figure 32. Chemical structures of compounds 181 and 182.

\section{Conclusions}

The fungi in deep-sea environments are very diverse and abundant, making them a versatile reservoir of metabolites with both new structures and bioactivities that can be of potential use, acting as leading 
compounds to synthesize new modern medicine. Although the research on deep-sea fungi is not as up-to-date as the research on fungi in other environments such as terrestrial soil, fresh water, and shallow marine areas due to difficulties in both sample collection and fungal cultivation methods, more and more fungi have been cultivated from the deep sea based on culture-dependent methods. These deep-sea fungi can provide a potential source for natural bioactive product screening and new drug discovery. Up to now, more than 180 new and/or bioactive secondary metabolites from deep-sea fungi with broad bioactivities, such as anticancer, antimicrobial, antifungal, anti-larval settlement, and antiviral, have been described in the literature. Most of the investigated bioactive compounds exhibit cytotoxic activity, then antimicrobial activity. These bioactive compounds not only help deep-sea fungi to defend themselves against predators in the natural ecosystem, but also have the potential of becoming treatments for human diseases and probes for new biological targets. Work to isolate fungi from deep-sea environments and characterize their bioactive metabolites is underway and is of increased importance due to the urgent need for new drugs to overcome emerging and drug-resistant diseases.

\section{Acknowledgments}

This work was supported by the National Natural Science Foundation of China $(31272081,31471810)$, the Jiangsu Science and Technology Support Program (BE2012372), and the Research Fund for the Doctoral Program of Higher Education (20130091110036).

\section{Conflicts of Interest}

The authors declare no conflict of interest.

\section{References}

1. Park, Y.C.; Gunasekera, S.P.; Lopez, J.V.; McCarthy, P.J.; Wright, A.E. Metabolites from the marine-derived fungus Chromocleista sp. isolated from a deep-water sediment sample collected in the Gulf of Mexico. J. Nat. Prod. 2006, 69, 580-584.

2. Swathi, J.; Narendra, K.; Sowjanya, K.M.; Satya, A.K. Evaluation of biologically active molecules isolated from obligate marine fungi. Mintage J. Pharm. Med. Sci. 2013, 2, 45-47.

3. Mahé, S.; Rédou, V.; Calvez, T.L.; Vandenkoornhuyse, P.; Burgaud, G. Fungi in deep-sea environments and metagenomics. In The Ecological Genomics of Fungi; Martin, F., Ed.; John Wiley \& Sons, Inc.: Hoboken, NJ, USA, 2013; pp. 325-354.

4. Hua, W.; Chen, X.; Cui, X. Preliminary study of deep-sea fungi and their bioactive secondary metabolites. In Proceedings of the Eleventh National Symposia of Chinese Medicine and Natural Products, Shenyang, China, 19-20 October 2011; p. 46. (In Chinese)

5. Yu, L. Identification and biological activity evaluation of three microbial strains isolated from deep-sea sediments. Master's Thesis, The Third Institute of Oceanography, State Oceanic Administration, Xiamen, 2011. (In Chinese)

6. Nagano, Y.; Nagahama, T. Fungal diversity in deep-sea extreme environments. Fungal Ecol. 2012, $5,463-471$. 
7. Roth Jr, F.J.; Orpurt, P.A.; Ahearn, D.G. Occurrence and distribution of fungi in a subtropical marine environment. Can. J. Bot. 1964, 42, 375-383.

8. Fredimoses, M.; Zhou, X.; Lin, X.; Tian, X.; Ai, W.; Wang, J.; Liao, S.; Liu, J.; Yang, B.; Yang, X. New prenylxanthones from the deep-sea derived fungus Emericella sp. SCSIO 05240. Mar. Drugs 2014, 12, 3190-3202.

9. Wu, G.; Sun, X.; Yu, G.; Wang, W.; Zhu, T.; Gu, Q.; Li, D. Cladosins A-E, hybrid polyketides from a deep-sea-derived fungus, Cladosporium sphaerospermum. J. Nat. Prod. 2014, 77, 270-275.

10. Blunt, J.W.; Copp, B.R.; Munro, M.H.; Northcote, P.T.; Prinsep, M.R. Review: Marine natural products. Nat. Prod. Rep. 2005, 22, 15-61.

11. Blunt, J.W.; Copp, B.R.; Munro, M.H.; Northcote, P.T.; Prinsep, M.R. Review: Marine natural products. Nat. Prod. Rep. 2004, 21, 1-49.

12. Thaler, A.D.; van Dover, C.L.; Vilgalys, R. Ascomycete phylotypes recovered from a Gulf of Mexico methane seep are identical to an uncultured deep-sea fungal clade from the Pacific. Fungal Ecol. 2012, 5, 270-273.

13. DeLong, E.F.; Pace, N.R. Environmental diversity of bacteria and archaea. Syst. Biol. 2001, 50, $470-478$.

14. Sogin, M.L.; Morrison, H.G.; Huber, J.A.; Welch, D.M.; Huse, S.M.; Neal, P.R.; Arrieta, J.M.; Herndl, G.J. Microbial diversity in the deep sea and the underexplored "rare biosphere". Proc. Natl. Acad. Sci. 2006, 103, 12115-12120.

15. Luna, G.M.; Stumm, K.; Pusceddu, A.; Danovaro, R. Archaeal diversity in deep-sea sediments estimated by means of different terminal-restriction fragment length polymorphisms (T-RFLP) protocols. Curr. Mircrobiol. 2009, 59, 356-361.

16. Nagano, Y.; Nagahama, T.; Hatada, Y.; Nunoura, T.; Takami, H.; Miyazaki, J.; Takai, K.; Horikoshi, K. Fungal diversity in deep-sea sediments-the presence of novel fungal groups. Fungal Ecol. 2010, 3, 316-325.

17. Singh, P.; Raghukumar, C.; Verma, P.; Shouche, Y. Assessment of fungal diversity in deep-sea sediments by multiple primer approach. World J. Microbiol. Biotechnol. 2012, 28, 659-667.

18. Takami, H.; Inoue, A.; Fuji, F.; Horikoshi, K. Microbial flora in the deepest sea mud of the Mariana Trench. FEMS Microbiol. Lett. 1997, 152, 279-285.

19. Raghukumar, C.; Raghukumar, S.; Sheelu, G.; Gupta, S.M.; Nath, B.N.; Rao, B.R. Buried in time: Culturable fungi in a deep-sea sediment core from the Chagos Trench, Indian Ocean. Deep Sea Res. Oceanogr. Res. Pap. 2004, 51, 1759-1768.

20. Zhang, X.; Zhang, Y.; Xu, X.; Qi, S. Diverse deep-sea fungi from the South China Sea and their antimicrobial activity. Curr. Microbiol. 2013, 67, 525-530.

21. You, J.; Dai, H.; Chen, Z.; Liu, G.; He, Z.; Song, F.; Yang, X.; Fu, H.; Zhang, L.; Chen, X. Trichoderone, a novel cytotoxic cyclopentenone and cholesta-7,22-diene-3 $\beta, 5 \alpha, 6 \beta$-triol, with new activities from the marine-derived fungus Trichoderma sp. J. Ind. Microbiol. Biotechnol. 2010, 37, 245-252.

22. Lai, X.; Cao, L.; Tan, H.; Fang, S.; Huang, Y.; Zhou, S. Fungal communities from methane hydrate-bearing deep-sea marine sediments in South China Sea. ISME J. 2007, 1, 756-762. 
23. Zhang, X.; Xu, X.; Peng, J.; Ma, C.; Nong, X.; Bao, J.; Zhang, G.; Qi, S. Antifouling potentials of eight deep-sea-derived fungi from the South China Sea. J. Ind. Microbiol. Biotechnol. 2014, $41,741-748$.

24. Wu, G.; Lin, A.; Gu, Q.; Zhu, T.; Li, D. Four new chloro-eremophilane sesquiterpenes from an antarctic deep-sea derived fungus, Penicillium sp. PR19N-1. Mar. Drugs 2013, 11, 1399-1408.

25. Wu, G.; Ma, H.; Zhu, T.; Li, J.; Gu, Q.; Li, D. Penilactones A and B, two novel polyketides from Antarctic deep-sea derived fungus Penicillium crustosum PRB-2. Tetrahedron 2012, 68, 9745-9749.

26. Stock, A.; Breiner, H.; Pachiadaki, M.; Edgcomb, V.; Filker, S.; La Cono, V.; Yakimov, M.M.; Stoeck, T. Microbial eukaryote life in the new hypersaline deep-sea basin Thetis. Extremophiles 2012, 16, 21-34.

27. Xu, W.; Pang, K.; Luo, Z. High fungal diversity and abundance recovered in the deep-sea sediments of the Pacific Ocean. Microb. Ecol. 2014, 68, 688-698.

28. Sergeeva, N.G.; Kopytina, N.I. The first marine filamentous fungi discovered in the bottom sediments of the oxic/anoxic interface and in the bathyal zone of the Black Sea. Turkish J. Fish. Aquat. Sci. 2014, 14, 497-505.

29. Wu, J.; Gao, W.; Johnson, R.H.; Zhang, W.; Meldrum, D.R. Integrated metagenomic and metatranscriptomic analyses of microbial communities in the meso-and bathypelagic realm of North Pacific Ocean. Mar. Drugs 2013, 11, 3777-3801.

30. Zhang, X.; Tang, G.; Xu, X.; Nong, X.; Qi, S. Insights into deep-sea sediment fungal communities from the East Indian Ocean using targeted environmental sequencing combined with traditional cultivation. PLOS ONE 2014, 9, doi:10.1371/journal.pone.0109118.

31. Borse, B.D.; Borse, K.N.; Pawar, N.S.; Tuwar, A.R. Marine fungi from India-XII. A revised check list. Indian J. Geo-Mar. Sci. 2013, 42, 110-119.

32. Xu, W.; Li, G.; Huang, X.; Luo, Z. Fungal diversity study in the deep sea sediments of three oceans by culture-dependent approach. J. Appl. Oceanogr. 2015, 34, 103-110. (In Chinese)

33. Hao, W. Fungal diversity in The Atlantic Ocean and the South China Sea deep-sea sediments and screening of the low-temperature enzyme producing strains from the extreme environment. Master's Thesis, Xiamen University, Xiamen, China, 2014. (In Chinese)

34. Bhadury, P.; Bik, H.; Lambshead, J.D.; Austen, M.C.; Smerdon, G.R.; Rogers, A.D. Molecular diversity of fungal phylotypes co-amplified alongside nematodes from coastal and deep-sea marine environments. PLoS ONE 2011, doi:10.1371/journal.pone.0026445.

35. Takishita, K.; Tsuchiya, M.; Reimer, J.D.; Maruyama, T. Molecular evidence demonstrating the basidiomycetous fungus Cryptococcus curvatus is the dominant microbial eukaryote in sediment at the Kuroshima Knoll methane seep. Extremophiles 2006, 10, 165-169.

36. Nagahama, T.; Takahashi, E.; Nagano, Y.; Abdel Wahab, M.A.; Miyazaki, M. Molecular evidence that deep-branching fungi are major fungal components in deep-sea methane cold-seep sediments. Environ. Microbiol. 2011, 13, 2359-2370.

37. Le Calvez, T.; Burgaud, G.; Mahé, S.; Barbier, G.; Vandenkoornhuyse, P. Fungal diversity in deep-sea hydrothermal ecosystems. Appl. Environ. Microb. 2009, 75, 6415-6421.

38. Jebaraj, C.S.; Raghukumar, C.; Behnke, A.; Stoeck, T. Fungal diversity in oxygen-depleted regions of the Arabian Sea revealed by targeted environmental sequencing combined with cultivation. FEMS Microbiol. Ecol. 2010, 71, 399-412. 
39. Farce, A.; Loge, C.; Gallet, S.; Lebegue, N.; Carato, P.; Chavatte, P.; Berthelot, P.; Lesieur, D. Docking study of ligands into the colchicine binding site of tubulin. J. Enzym. Inhib. Med. Chem. 2004, 19, 541-547.

40. Meng, J.; Geng, R.; Zhou, C. Benzene and imidazoles drug research progress. Chin. J. New Drugs 2009, 18, 1505-1514.

41. Yao, Q.; Wang, J.; Zhang, X.; Nong, X.; Xu, X.; Qi, S. Cytotoxic polyketides from the deep-seaderived fungus Engyodontium album DFFSCS021. Mar. Drugs 2014, 12, 5902-5915.

42. Chen, X.; Li, C.; Cui, C.; Hua, W.; Zhu, T.; Gu, Q. Nine new and five known polyketides derived from a deep sea-sourced Aspergillus sp. 16-02-1. Mar. Drugs 2014, 12, 3116-3137.

43. Guo, W.; Peng, J.; Zhu, T.; Gu, Q.; Keyzers, R.A.; Li, D. Sorbicillamines A-E, nitrogen-containing sorbicillinoids from the deep-sea-derived fungus Penicillium sp. F23-2. J. Nat. Prod. 2013, $76,2106-2112$.

44. Yu, G.; Wu, G.; Zhu, T.; Gu, Q.; Li, D. Cladosins F and G, two new hybrid polyketides from the deep-sea-derived Cladosporium sphaerospermum 2005-01-E3. J. Asian Nat. Prod. Res. 2014, $17,1-5$.

45. Cui, X.; Li, C.; Wu, C., Hua, W. Metabolites of Paecilomyces lilacinus ZBY-1 from deep-sea water and their antitumor activity. J. Int. Pharm. Res. 2013, 40, 177-186. (In Chinese)

46. Li, Y.; Ye, D.; Shao, Z.; Cui, C.; Che, Y. A sterol and spiroditerpenoids from a Penicillium sp. isolated from a deep sea sediment sample. Mar. Drugs 2012, 10, 497-508.

47. Lin, X.; Zhou, X.; Wang, F.; Liu, K.; Yang, B.; Yang, X.; Peng, Y.; Liu, J.; Ren, Z.; Liu, Y. A new cytotoxic sesquiterpene quinone produced by Penicillium sp. F00120 isolated from a deep sea sediment sample. Mar. Drugs 2012, 10, 106-115.

48. Ji, C.; Sun, S.; Cai, S. Studies on the active secondary metabolites from the deep-sea-derived fungus Aspergillus CXCTD-06-6a, Chin. J. Mar. Drugs 2011, 30, 1-6. (In Chinese)

49. Tian, L.; Cai, S.; Li, D.; Lin, Z.; Zhu, T.; Fang, Y.; Liu, P.; Gu, Q.; Zhu, W. Two new metabolites with cytotoxicities from deep-sea fungus, Aspergillus sydowi YH11-2. Arch. Pharm. Res. 2007, 30, 1051-1054.

50. Shang, Z.; Li, X.; Meng, L.; Li, C.; Gao, S.; Huang, C.; Wang, B. Chemical profile of the secondary metabolites produced by a deep-sea sediment-derived fungus Penicillium commune SD-118. Chin. J. Oceanol. Limnol. 2012, 30, 305-314.

51. Li, C.; Li, X.; An, C.; Wang, B. Prenylated indole alkaloid derivatives from marine sediment-derived fungus Penicillium paneum SD-44. Helv. Chim. Acta 2014, 97, 1440-1444.

52. Peng, J.; Zhang, X.; Tu, Z.; Xu, X.; Qi, S. Alkaloids from the deep-sea-derived fungus Aspergillus westerdijkiae DFFSCS013. J. Nat. Prod. 2013, 76, 983-987.

53. Lin, A.; Wu, G.; Gu, Q.; Zhu, T.; Li, D. New eremophilane-type sesquiterpenes from an Antarctic deep-sea derived fungus, Penicillium sp. PR19 N-1. Arch. Pharm. Res. 2014, 37, 839-844.

54. Chen, L.; Li, D.H.; Cai, S.X.; Wang, F.P.; Xiao, X.; Gu, Q.Q. A new cytotoxic metabolite from a deep sea derived fungus, Phialocephala sp. Acta Pharm. Sin. 2010, 45, 1275-1278.

55. Li, C.; Li, X.; Gao, S.; Lu, Y.; Wang, B. Cytotoxic anthranilic acid derivatives from deep sea sediment-derived fungus Penicillium paneum SD-44. Mar. Drugs 2013, 11, 3068-3076. 
56. Chen, X.; Li, C.; Hua, W. Metabolites of Aspergillus sp. 16-02-1 isolated from a deep sea sediment and preliminary test of their antitumor and antifungal activities. Chin. J. Mar. Drugs 2013, 32, 1-10. (In Chinese)

57. Fredimoses, M.; Zhou, X.; Ai, W.; Tian, X.; Yang, B.; Lin, X.; Xian, J.; Liu, Y. Westerdijkin A, a new hydroxyphenylacetic acid derivative from deep sea fungus Aspergillus westerdijkiae SCSIO 05233. Nat. Prod. Res. 2015, 29, 158-162.

58. Cui, X.; Li, C.; Wu, C., Hua, W. Secondary metabolites of Paecilomyces lilacinus ZBY-1 and their antitumor activity. J. Int. Pharm. Res. 2013, 40, 765-771. (In Chinese)

59. Li, D.; Wang, F.; Xiao, X.; Fang, Y.; Zhu, T.; Gu, Q.; Zhu, W. Trisorbicillinone A, a novel sorbicillin trimer, from a deep sea fungus, Phialocephala sp. FL30r. Tetrahedron Lett. 2007, $48,5235-5238$.

60. Li, D.; Wang, F.; Cai, S.; Zeng, X.; Xiao, X.; Gu, Q.; Zhu, W. Two new bisorbicillinoids isolated from a deep-sea fungus, Phialocephala sp. FL30r. J. Antibiot. 2007, 60, 317-320.

61. Li, Y.; Ye, D.; Chen, X.; Lu, X.; Shao, Z.; Zhang, H.; Che, Y. Breviane spiroditerpenoids from an extreme-tolerant Penicillium sp. isolated from a deep sea sediment sample. J. Nat. Prod. 2009, $72,912-916$.

62. Dong, Y.; Cui, C.; Li, C.; Hua, W.; Wu, C.; Zhu, T.; Gu, Q. Activation of dormant secondary metabolite production by introducing neomycin resistance into the deep-sea fungus, Aspergillus versicolor ZBY-3. Mar. Drugs 2014, 12, 4326-4352.

63. Zhao, Y.; Chen, H.; Shang, Z.; Jiao, B.; Yuan, B.; Sun, W.; Wang, B.; Miao, M.; Huang, C. SD118-xanthocillin X (1), a novel marine agent extracted from Penicillium commune, induces autophagy through the inhibition of the MEK/ERK pathway. Mar. Drugs 2012, 10, 1345-1359.

64. Cai, S.; Zhu, T.; Du, L.; Zhao, B.; Li, D.; Gu, Q. Sterigmatocystins from the deep-sea-derived fungus Aspergillus versicolor. J. Antibiot. 2011, 64, 193-196.

65. Sun, Y.; Takada, K.; Takemoto, Y.; Yoshida, M.; Nogi, Y.; Okada, S.; Matsunaga, S. Gliotoxin analogues from a marine-derived fungus, Penicillium sp., and their cytotoxic and histone methyltransferase inhibitory activities. J. Nat. Prod. 2011, 75, 111-114.

66. Niu, S.; Liu, D.; Hu, X.; Proksch, P.; Shao, Z.; Lin, W. Spiromastixones A-O, antibacterial chlorodepsidones from a deep-sea-derived Spiromastix sp. fungus. J. Nat. Prod. 2014, 77, 1021-1030.

67. Liu, F.; Xia, J.; Wang, W. Isolation and identification of two terphenyl compounds from Aspergillus candidus metabolites. J. Xiamen Univ. 2013, 52, 670-674. (In Chinese)

68. Tian, Y.; Lin, X.; Liu, J.; Kaliyaperumal, K.; Ai, W.; Ju, Z.; Yang, B.; Wang, J.; Yang, X.; Liu, Y. Ascomycotin A, a new citromycetin analogue produced by Ascomycota sp. Ind19F07 isolated from deep sea sediment. Nat. Prod. Res. 2014, 29, 1-7.

69. Kong, X.; Cai, S.; Zhu, T.; Gu, Q.; Li, D.; Luan, Y. Secondary metabolites of a deep sea derived fungus Aspergillus versicolor CXCTD-06-6a and their bioactivity. J. Ocean. Univ. China 2014, 13, 691-695. 
70. Liu, H.; Kong, M. Zheng, Y. Studies on secondary metabolites produced by Aspergillus sp. SCSIOW3 isolated from deep sea and their anti-A $\beta$ peptide aggregation activity. Chin. J. Mar. Drugs 2014, 33, 71-74. (In Chinese)

(C) 2015 by the authors; licensee MDPI, Basel, Switzerland. This article is an open access article distributed under the terms and conditions of the Creative Commons Attribution license (http://creativecommons.org/licenses/by/4.0/). 